\title{
Seasonal and interannual variations in the distributions of tuna-associated dolphins in the eastern tropical Pacific Ocean
}

\author{
Paul C. Fiedler ${ }^{1}$ And Cleridy E. Lennert-Cody ${ }^{2}$ \\ Contacte-mail: Paul.Fiedler@noaa.gov
}

\begin{abstract}
Seasonal and interannual (El Niño-La Niña) variations in dolphin distributions in the eastern tropical Pacific Ocean have not been quantified, in spite of an extensive research vessel database. Fisheries observer data from the yellowfin tuna purse-seine fishery, collected year-round from 1986 through 2015, were used to construct a binned spatiotemporal dataset of the presence/absence of spotted, spinner and common dolphin schools by month and $1^{\circ}$ area. Distribution patterns were predicted from generalised additive logistic regression models applied to the binned data, with dynamic predictors of surface temperature and salinity, thermocline depth and a stratification index. The dolphin taxa, especially common dolphins, show some niche separation in relation to these variables. Predicted distributions for each taxon showed seasonal and interannual differences. Spotted and spinner dolphins responded to changes in the position and size of the eastern Pacific warm pool and avoided the equatorial cold tongue in September-October and during La Niña. Common dolphins responded to seasonal and interannual changes in the Costa Rica Dome, the cold tongue, and the coastal upwelling habitat along Baja California, Peru and Ecuador. These predicted temporal variations are consistent with changes in preferred habitat driven by environmental variability.
\end{abstract}

KEYWORDS: DISTRIBUTION; EL NIÑO; MODELLING; OCEANOGRAPHY; PACIFIC OCEAN

\section{INTRODUCTION}

Species distribution patterns and changes in these patterns over time are integral to studies of habitat use, population dynamics, and ecological and evolutionary relationships. Species distribution models relate spatial patterns of species to environmental variables that vary in space and perhaps time. Such models are fundamental to understanding habitat utilisation in both geographical and ecological (niche) space. More practically, they are also useful to objectively fill gaps in survey data, although extrapolation beyond the spatial or temporal extent of the observations is challenging (Redfern et al., 2017).

The eastern tropical Pacific Ocean (ETP) is a significant part of the global tropical ocean and includes several water masses and habitat types (Fig. 1) that can influence the distribution of species (Ballance et al., 2006; Fiedler and Talley, 2006). Among the 10 or more species of dolphins that reside in the ETP, three species have been the focus of much research and management concern because of their involvement with the yellowfin tuna (Thunnus albacares) purse-seine fishery (Hall, 1998; National Research Council, 1992): the spotted dolphin; the spinner dolphin; and the common dolphin. The association between tuna and dolphins in the region is thought to be related to unusual habitat conditions (Scott et al., 2012).

The eastern Pacific warm pool, characterised by warm surface temperature and high stratification, is part of the warm, low-salinity tropical surface water (TSW) mass. Surface salinity is lowest in the Gulf of Panama. This water mass is highly stratified, with a shallow mixed layer depth, which results in a shallow oxygen minimum layer (Fiedler and Talley, 2006). The warm pool is the centre of the ETP tuna purse-seine fishery (IATTC, 2018) that targets yellowfin tuna associated with dolphins. South of the warm pool, the equatorial cold tongue is cool, moderate-salinity water overlying an equatorial thermocline ridge resulting from equatorial upwelling. The equatorial front is the northern boundary of the equatorial cold tongue. The countercurrent thermocline ridge lies along $10^{\circ} \mathrm{N}$, associated with the eastward North Equatorial Countercurrent on the south side and the westward North Equatorial Current on the north side. The Costa Rica Dome is the eastern end of this thermocline ridge and is a site of oceanic upwelling and enhanced productivity (Fiedler, 2002).

Cold, low-salinity eastern boundary currents, the California and Peru Currents, flow into the ETP along the coasts of North and South America. These currents are the eastern, equatorward segments of the North and South Pacific subtropical gyres. The subtropical gyres encompass warm, high-salinity subtropical surface water masses. Productivity is enhanced seasonally in the regions of coastal and oceanic upwelling: the eastern boundary currents, the equatorial cold tongue and the Costa Rica Dome.

The spatial patterns illustrated as climatologies in Fig. 1 are dynamic both within and between years. Seasonal and ENSO (El Niño-Southern Oscillation)-related variability in ETP oceanography are reviewed in Fiedler and Talley (2006) and Wang and Fiedler (2006). Interannual variability due to ENSO and seasonal variability are known to be of comparable magnitude in the ETP (Fiedler et al., 2013). The intertropical convergence zone (ITCZ) reaches its northern extreme in September (Hastenrath, 2002) and southeast trade winds blow across the equator. Equatorial upwelling is high and the cold tongue is pronounced. To the north of the cold tongue, seasonal temperature changes are slight, but warming and cooling do occur to the north and south of a 

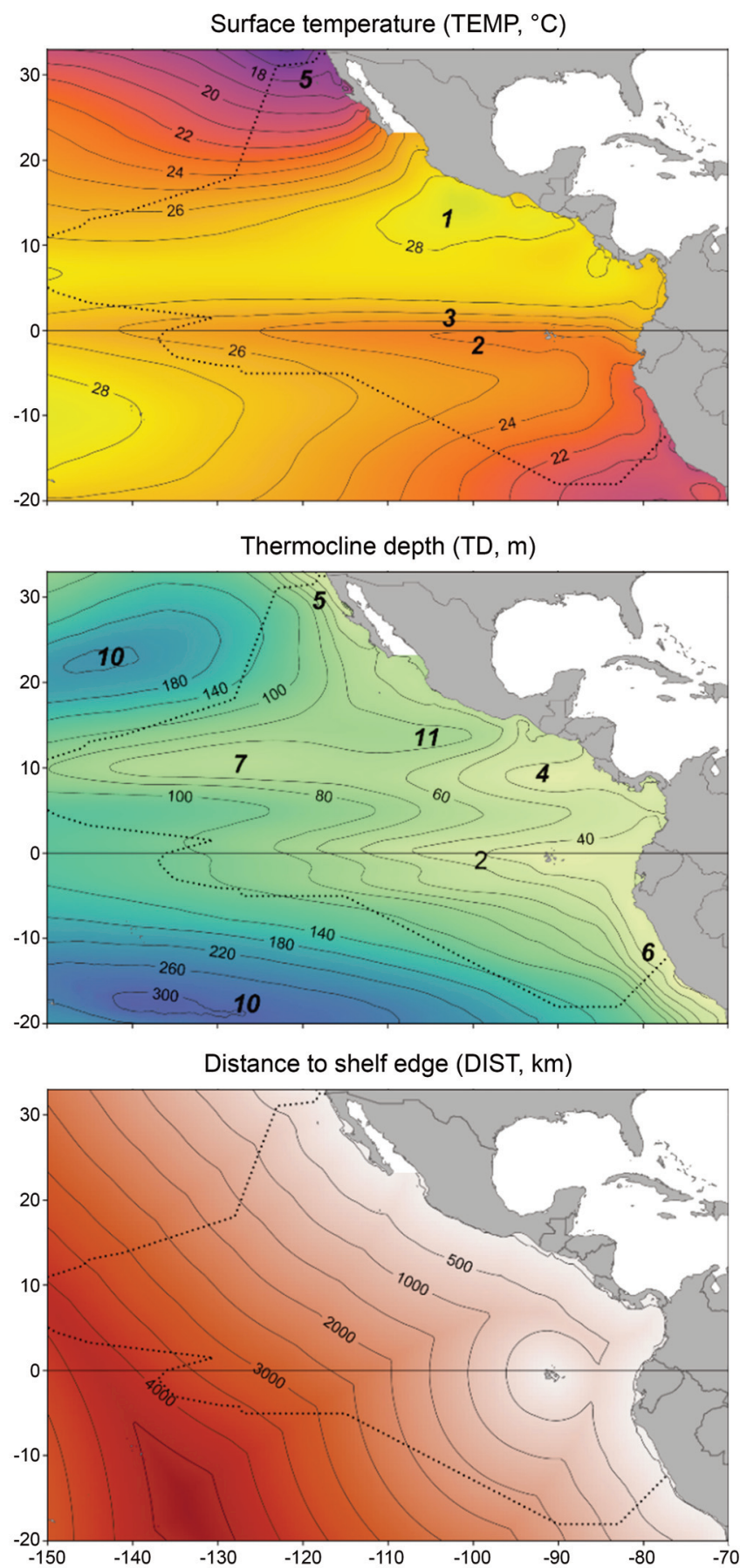

Surface salinity (SAL, psu)

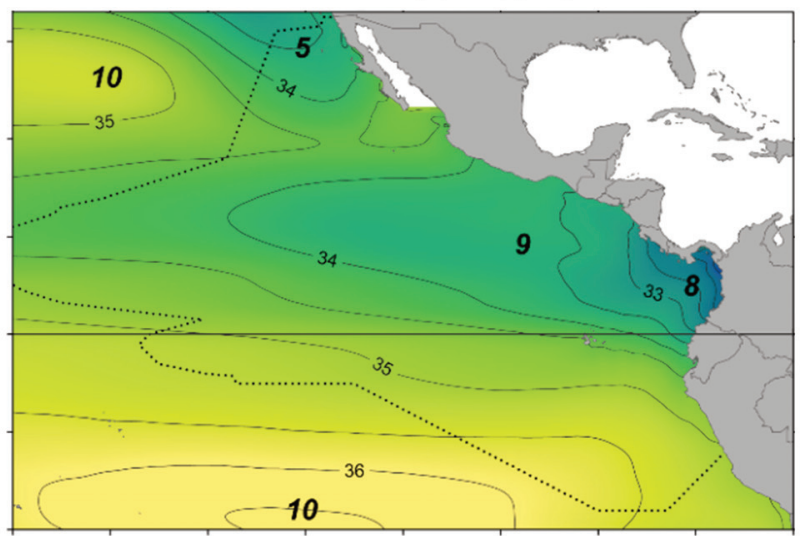

Stratification index $\left(\mathrm{SI},{ }^{\circ} \mathrm{C}\right)$

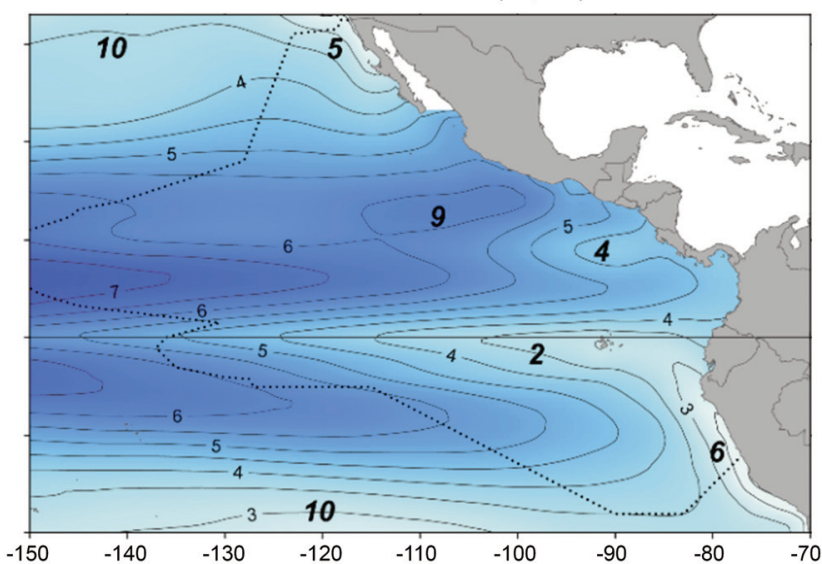

1 - Eastern Pacific warm pool

2 - Equatorial cold tongue

3 - Equatorial front

4 - Costa Rica Dome

5 - California Current

6 - Peru Current

7 - Countercurrent thermocline ridge

8 - Gulf of Panama

9 - Tropical surface water

10 - Subtopical surface water

11 - Tehuantepec Bowl

Fig. 1. Climatologies of oceanographic predictor variables (1980-2015) and important environmental features in the eastern tropical Pacific. Dotted line marks the extent of Southwest Fisheries Science Center (SWFSC) research vessel surveys.

thermal equator at $\sim 10^{\circ} \mathrm{N}$. Salinity of tropical waters north of the equator is lower in October-November due to seasonal rains associated with the ITCZ. Seasonal winds force local changes in surface temperature, circulation and upwelling along the equator, the Central American coast and at the Costa Rica Dome.

ENSO changes are only partially analogous to seasonal changes. ENSO changes in winds and in surface and subsurface temperature are most pronounced along the equator, but similar changes occur in tropical waters north of the equator (Wang and Fiedler, 2006). During warm El Niño events, surface waters are warmer and the thermocline is deeper throughout the region, more so along the equator than to the north. Trade winds are weak, so that wind-driven upwelling and nutrient input for phytoplankton production are decreased. During La Niña, the cold phase of ENSO, the changes in the ETP go the opposite way, but with a somewhat lesser magnitude (An and Jin, 2004).

Comparison of the species distributions estimated from research vessel surveys (Gerrodette et al., 2008) for the dominant dolphin species in the ETP in warm and cold years suggests that species/stock ranges may expand or contract in response to environmental changes (Fiedler and Reilly, 1994; Ballance et al., 2006). Pantropical spotted dolphins are globally distributed in tropical and some subtropical waters, from $30-40^{\circ} \mathrm{N}$ to $20-40^{\circ} \mathrm{S}$. Offshore pantropical spotted dolphins (Stenella attenuata attenuata, Gray 1846) are the most abundant species in the ETP (Gerrodette and Forcada, 
2005). Spinner dolphins (S. longirostris, Gray 1828), in common with spotted dolphins, are circumtropical but show a different pattern of sub-specific differentiation in the eastern Pacific than spotted dolphins do (Leslie and Morin, 2018). There are several distinct sub-species of spinner dolphin, with the most abundant being the eastern spinner dolphin (S. l. orientalis, Perrin 1990). A third ETP spinner stock, referred to as 'whitebelly' spinners, is thought to be a hybrid of the eastern spinner and Gray's spinner (S. l. longirostris, Perrin 2010; Perrin, 2018b). Whitebelly spinners are found in the region to the west and south of eastern spinner dolphins in the ETP. Two forms of common dolphins occur within the ETP: short-beaked common dolphins (Delphinus delphis delphis Linnaeus 1758) are the offshore warm-temperate form found throughout the ETP and globally, while the long-beaked form (D. d. capensis, formerly D. capensis; Committee on Taxonomy, 2017) are found in cooler nearshore waters to the north and south of the yellowfin tuna fishery (Hamilton et al., 2009).

Although the ETP has some of the most extensive cetacean line-transect survey coverage in the world (Kaschner et al., 2012), there are gaps in temporal coverage (Fig. 2), which results in an incomplete picture of inter-annual and interseasonal changes in dolphin species distributions. For example, the only recent ENSO warm/cold event adequately covered by research vessel surveys was 1986-88; the first year of the major 1997-99 event was missed. In addition, all research vessel surveys that completely cover the ETP have been in August-November (Gerrodette et al., 2008), and therefore these data cannot resolve seasonality of distributions.

An alternative source of data for dolphins in the ETP are the marine mammal sightings data collected by fisheries' observers onboard tuna vessels searching for and setting on tuna associated with dolphins (Bayliff, 2001; Wahlen, 1986). For decades, purse-seiners fishing for yellowfin tuna set nets on dolphins, primarily pantropical spotted dolphin, eastern spinner dolphin and common dolphin, to catch the associated tuna (National Research Council, 1992). Observers have been placed aboard large purse-seiners to monitor dolphin bycatch (Bayliff, 2001; National Research Council, 1992) and, more recently, to collect catch and bycatch data for many more species involved in the purse-seine fishery (Joseph, 1994). The tuna vessel observer data (TVOD) spatial coverage within the ETP is similar to that of the research vessel data, while the temporal coverage is much more extensive (Fig. 2). However, as fishery-dependent data, the TVOD have a variety of known biases (Buckland and Anganuzzi, 1988; Lennert-Cody et al., 2001; 2016; Ward, $2005)$ that must be taken into consideration.

The objectives of this paper were to extend understanding of dolphin distributions in the ETP by describing seasonal and interannual variation in dolphin habitat use and to demonstrate that useful inferences about dolphin populations

(A) SWFSC effort, $10^{3} \mathrm{~km}$

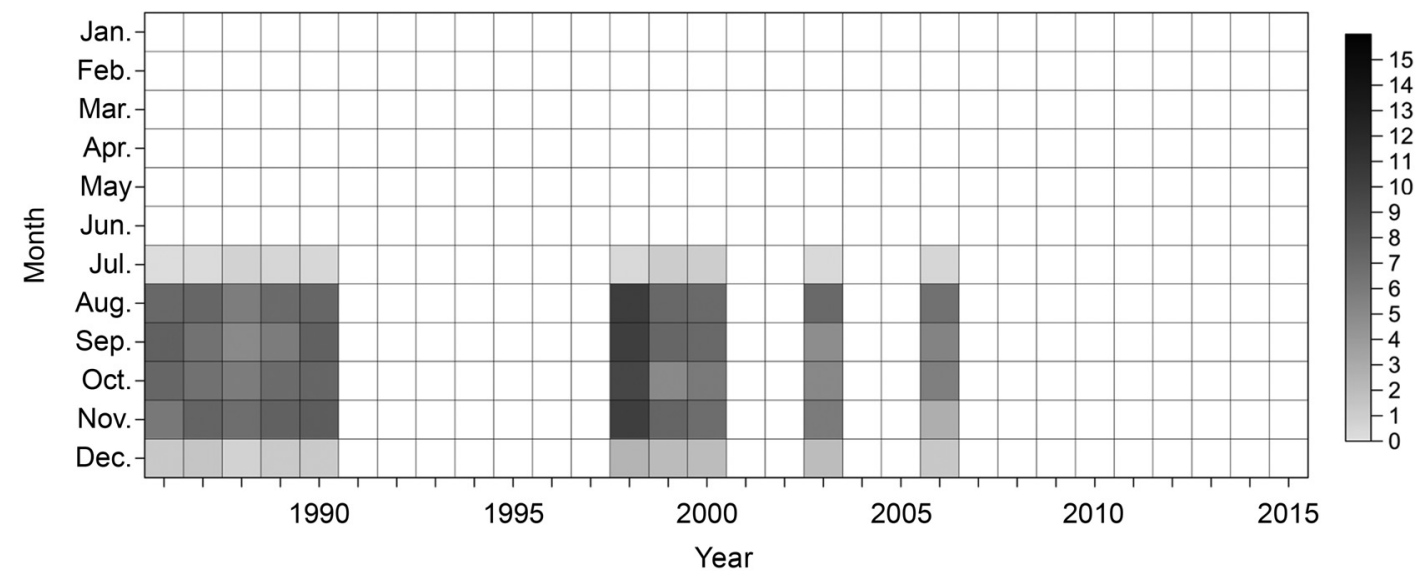

(B) TVOD effort, $10^{3} \mathrm{~km}$

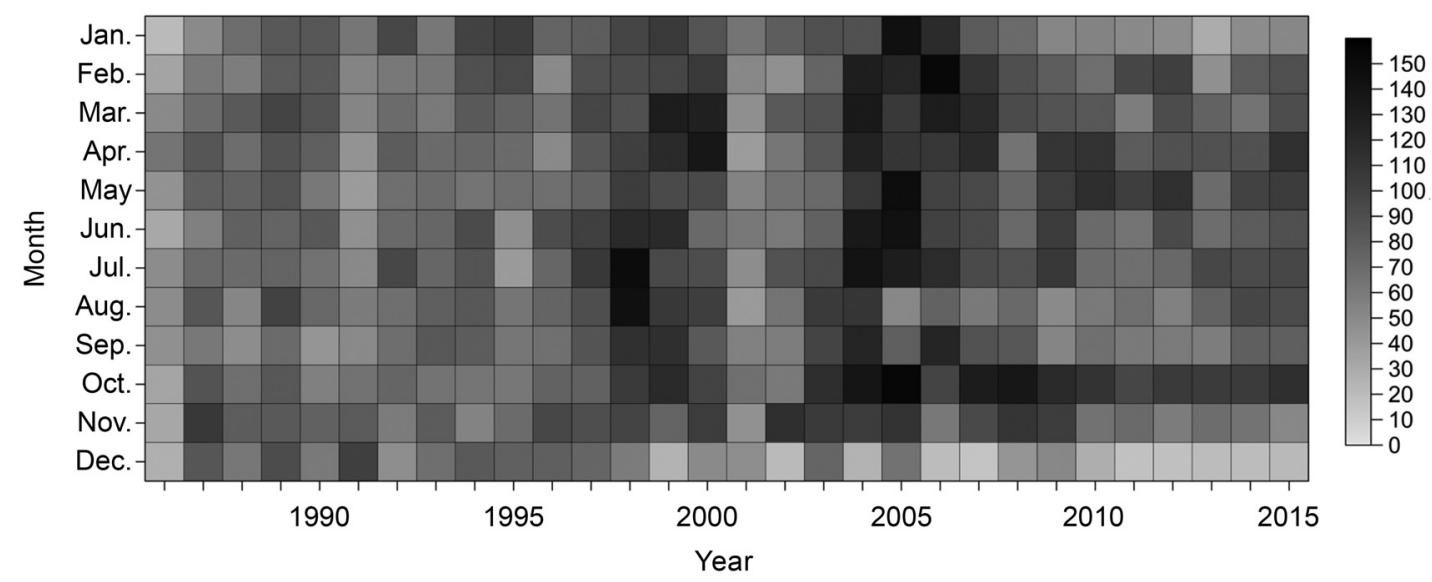

Fig. 2. Total search effort for ETP dolphins by month and year: (A) SWFSC research vessel surveys; and (B) tuna vessel observers. Search effort is km of search, or tuna vessel trackline, while observers were on duty. 
can be derived from fishery observer data. TVOD, postprocessed to minimise the effects of known biases on the analyses, were used to explore questions that cannot be addressed using research vessel data, yielding original insights into seasonal and interannual movement patterns of tuna-associated dolphins. Species distribution models of presence-absence (the probability of one or more dolphin schools) were built for three taxa: spotted dolphin, spinner dolphin and common dolphin. Model projections are presented for the climatological spatial distributions and for differences between the seasonal extremes of March-April and September-October and between El Niño and La Niña years. These differences are interpreted as responses to seasonal and interannual changes in dolphin habitat, extending our knowledge of variability in the distributions of these rare top predators. Finally, the ecological significance of the modelled distributions and implied responses to seasonal and interannual variations in the environment are discussed.

\section{MATERIALS AND METHODS}

\section{Tuna vessel observer data}

TVOD were collected by Inter-American Tropical Tuna Commission (IATTC) observers aboard vessels of the international fleet and by National Marine Fisheries Service (NMFS) observers aboard US-flagged vessels. These data were processed and binned into $1^{\circ}$ monthly 'cells' for each of the years from 1986 through 2015. Prior to 1986, the sampling did not adequately represent all vessels participating in the fishery (Joseph, 1994). Spatial coverage of the 19862015 TVOD search effort is shown in Fig. 3. As has been observed previously (cf. Hall et al., 1999), fishing effort tends to increase south of the equator in the austral summer and extend much farther to the west, north of the equator in the boreal summer. Temporal variability of total search effort is illustrated in Fig. 2. TVOD dolphin sightings are collected when purse-seiners fishing on dolphin-associated tuna are actively searching. Thus, changes in coverage may be influenced by tuna availability and weather.

The unbinned data included information on vessel activity (e.g. searching, running, setting), positions, dates and times of various vessel activities, observer status (on/off duty) and dolphin school sighting information (species, school size) for each day during a vessel's trip. Data processing was designed to minimise known biases in the TVOD, which include non-random distribution of search effort and a tendency for dolphin sightings to be of schools associated with tuna (Buckland and Anganuzzi, 1988; Lennert-Cody et $a l ., 2001 ; 2016$ ), and a positive correlation between dolphin school size and tuna catch (Hall et al., 1999).

Search effort per $1^{\circ}$ monthly cell was computed and used to exclude cells where effort was too low to have been likely to represent adequate search for dolphin schools. Very low effort per cell could have occurred because vessels were simply transiting the area, and search during transit appears to have different characteristics to non-transit search (Lennert-Cody et al., 2016). Search effort by cell was computed as follows. Trip-days that did not have at least two valid positions and any days that had no period of on-duty searching (i.e. observer on-duty and vessel in search mode) were dropped. Then, during a trip-day, a 'search segment' was defined as any pair of records that corresponded to a period of on-duty searching. For every search segment that did not have known start and/or end positions, the positions were estimated from known position information as close in time as possible to the segments without position information. The distance spent searching (in $\mathrm{km}$ ) was then computed from each segment and summed over segments (or fractions thereof) within each cell. Only those cells with at least $50 \mathrm{~km}$ of search effort were retained for further analysis, assuming that this level of effort would have been adequate to detect dolphin schools if present; this excludes $38.7 \%$ of cells (mean search effort $=164.7 \mathrm{~km}$, median $=$ $99.4 \mathrm{~km})$.

Dolphin sightings were summarised by cell for those cells with more than $50 \mathrm{~km}$ of search effort. Spotted and spinner dolphins associated with tuna in the ETP can form pure- or mixed-species schools (Hall et al., 1999). In this analysis, sightings assigned to each species included both pure- and mixed-species schools. The majority of sightings recorded by observers were initially detected by the vessel crew although observers were instructed to make their own estimates of species composition and school size whenever possible. Because observers did not have access to highpowered searching equipment (and were not allowed to interfere with the searching process of the vessel crew), any sightings made only by the observer, without being referred by the crew, were deemed to be of questionable quality and therefore were also excluded from the analysis.

For sightings referred by the crew, observers made initial estimates of dolphin school size and species composition if they were able to adequately view the school. The observer made a final ('best') estimate of school size and species composition if the dolphins were later involved in a purseseine set. When available, observers' best estimates of school composition were used, otherwise their initial estimates were used (Table 1). For spotted dolphins, the estimates of species composition by the vessel crew were used if no observer estimates were available. Vessel crew sightings of spinner dolphins were not used because they were not recorded to stock. In addition, no vessel crew sighting data were used for common dolphins because the vessel crew did not distinguish between common dolphins and whitebelly spinner dolphins (the crew record both species as 'whitebelly' dolphin). To minimise potential bias in the reporting of dolphin schools that were associated with tuna (LennertCody et al., 2016) and the positive correlation of school size with tuna catch (Hall et al., 1999), neither the number of dolphin schools nor estimates of school size were used. The number of sightings per cell was converted into presence (one or more schools sighted) or absence (no schools sighted), independent of school size.

\section{Predictor variables}

Oceanographic predictor variables were extracted from composites of six ocean reanalysis datasets (Fiedler et al., 2017): ECDA v3.13; ESTOC v02 $\mathrm{c}^{4}$; GECCO2 v34 55

\footnotetext{
${ }^{3}$ www.gfdl.noaa.gov/ocean-data-assimilation/

${ }^{4}$ www.godac.jamstec.go.jp/estoc/

${ }^{5}$ icdc.zmaw.de/1/daten/reanalysis-ocean/gecco 2
} 
(A)

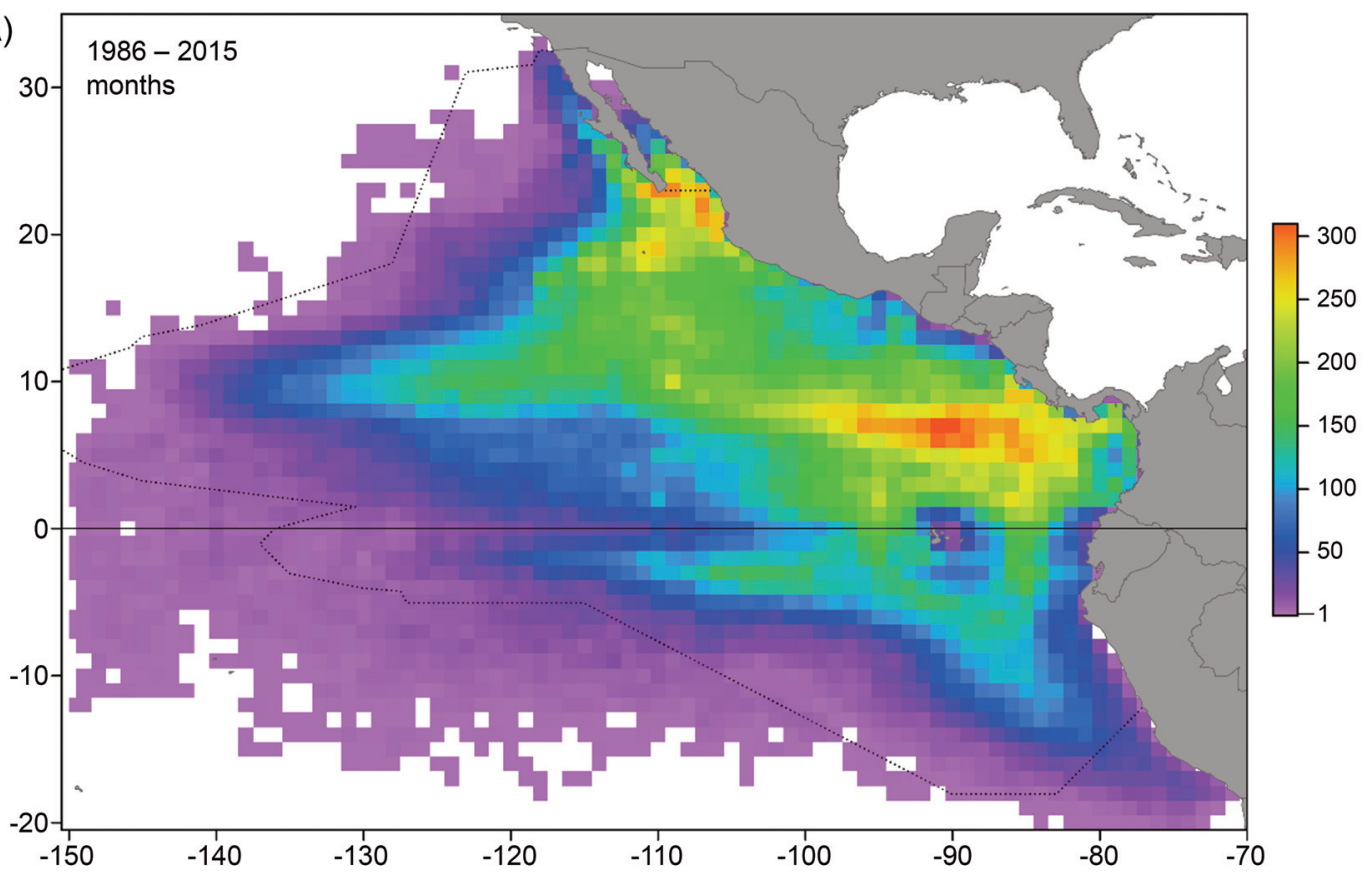

(B)
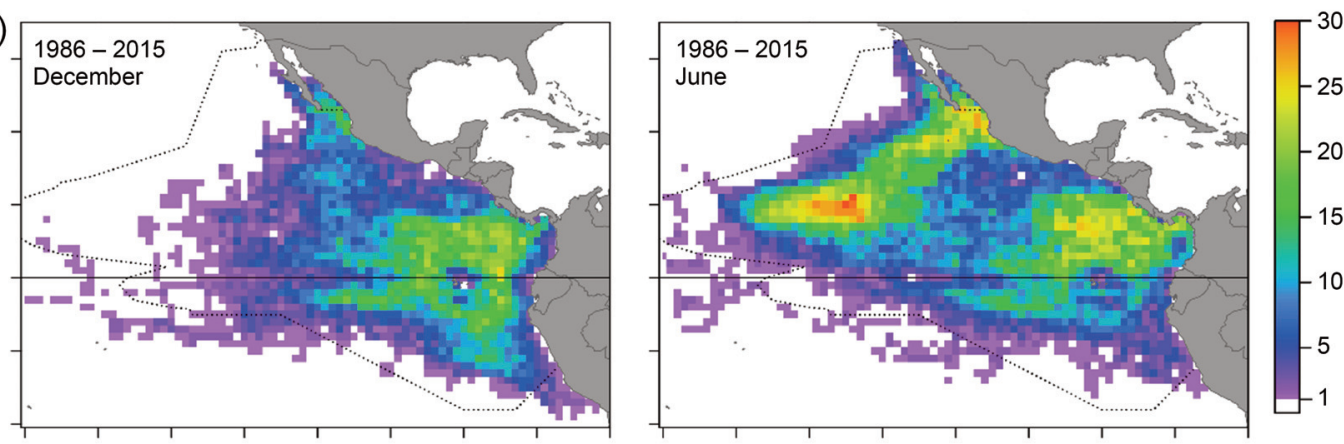

(C)
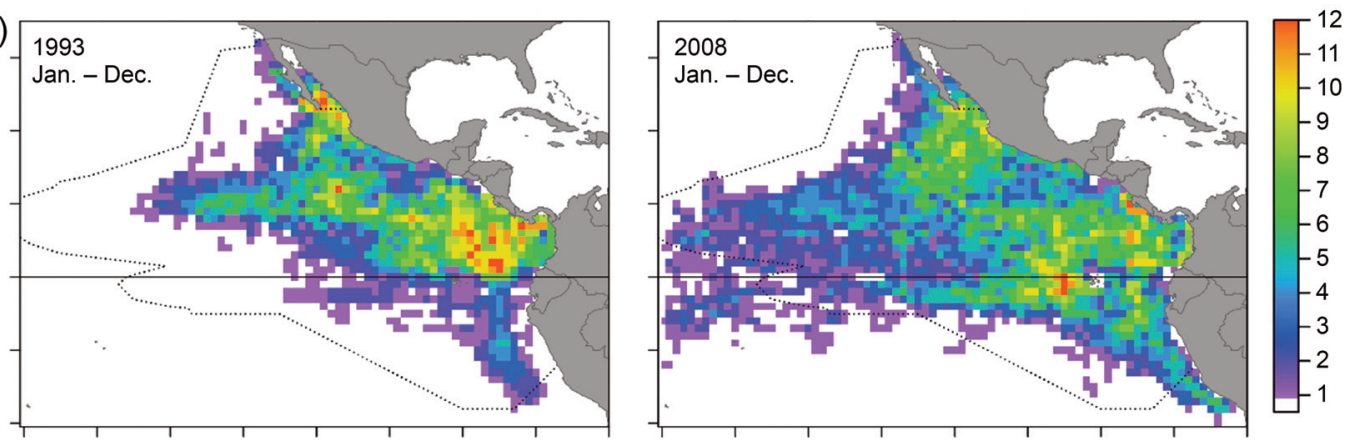

Fig. 3. (A) Coverage of tuna vessel observer data (TVOD) dolphin sightings, total number of months during 1986-2015 (scale is months, 360 total). (B) Yearly coverage of TVOD dolphin sightings data for the months of December and June, number of years during 1986-2015 for each month (scale is years, 30 total). (C) Monthly coverage of TVOD dolphin sightings data for two years, 1993 and 2008, illustrating extremes of yearly coverage. Dotted lines indicate the study area for SWFSC research vessel surveys (August-November in 1986-1990, 1998-2000, 2003, and 2006).

Table 1

TVOD dolphin sighting identifications, 1986-2015, proportions in pure and mixed schools and by quality of the identification: best (final, post-set) or initial estimate by the observer, or estimate by crew only. $N$ is the total number of sightings in the monthly $1^{\circ}$ cells.

\begin{tabular}{llrcc}
\hline & & Spotted & Eastern spinner & Common \\
\hline Observer best estimate & Pure & 0.36 & 0.10 & 0.44 \\
& Mixed & 0.32 & 0.64 & 0.01 \\
Observer initial estimate & Pure & 0.15 & 0.07 & 0.54 \\
& Mixed & 0.08 & 0.18 & 0.01 \\
Crew-only estimate & Pure & 0.06 & & \\
& Mixed & 0.02 & & 18,357 \\
$\mathrm{~N}=$ & & 173,556 & 53,266 & \\
\hline
\end{tabular}


GODAS $^{6}$; ORAS47; and SODA 3.3.1 ${ }^{8}$. Each of the monthly reanalysis data fields (temperature and salinity) were linearly interpolated onto 0.25 -deg longitude-latitude grids and at depths of $0,5,10,20,30, \ldots 500 \mathrm{~m}$ (MATLAB interp3). The six interpolations were then averaged to produce a composite to minimise biases and uncertainties in each of the six reanalyses, which use different inputs and methodologies (Balmaseda et al., 2015). Variables derived from the reanalysis data (thermocline depth and stratification index) were derived from the composited temperature and salinity fields. The monthly composites were then averaged on $1^{\circ}$ longitude-latitude grids for four oceanographic predictor variables: surface temperature (TEMP, $\left.{ }^{\circ} \mathrm{C}\right)$; salinity $(\mathrm{SAL}$, psu); thermocline depth (TD, m); and stratification index (SI, $\left.{ }^{\circ} \mathrm{C}\right)$. The thermocline was defined as the depth interval that included the upper decile $(10 \%)$ of $1 \mathrm{~m}$ temperature gradients in a $0-300 \mathrm{~m}$ depth profile of temperature; thermocline depth is the weighted mean of the depths of this set, with each depth weighted by the value of the $1 \mathrm{~m}$ temperature gradient. Stratification index is the standard deviation of temperature in the near-surface layer, 0-300m (Fiedler, 2010). A static fifth predictor variable, distance to the edge of the continental shelf (DIST, $\mathrm{km}$ ), was derived from the geomorphic features map (GSFM) of the global ocean (Harris et al., 2014), excluding smaller islands.

\section{Generalised additive models}

A logistic regression model was used to model the probability of one or more dolphin schools $(p)$ as a function of covariates using the R (v.3.4.0; R Development Core Team, 2017) generalised additive model (GAM) package 'mgcv' (v.1.8-4; Wood, 2011):

$$
\begin{aligned}
\operatorname{logit}(p) \sim & \operatorname{te}(\text { SAL,TEMP })+\mathrm{s}(\mathrm{TD})+\mathrm{s}(\mathrm{SI}) \\
& +\mathrm{s}(\mathrm{DIST})+\mathrm{s}(\text { effort })
\end{aligned}
$$

where TEMP and SAL were modelled as a tensor product smooth surface (te) to differentiate surface water masses, and the other predictors were modelled as univariate smooth terms based on thin plate regression splines. Correlations among the environmental predictor variables in our study ranged from 0.03 to 0.73 in absolute value (Table 2), but $\mathrm{mgcv}$ is robust to strong functional relationships among predictor variables (termed 'concurvity'; Wood, 2008). The gamma parameter was set to 1.4 (Wood, 2006) and a maximum of two degrees of freedom was allowed for each spline to capture non-linear relationships but limit overfitting. Search effort per cell (effort) was included as a covariate in the model to account for its possible effect on the probability of detecting presence.

A model was built for each species using all observed $1^{\circ}$ year-month presence/absence cells for the 1986-2015 period, with corresponding environmental data. Predictions for seasonal and ENSO periods used estimated parameters from these models but applied to climatological variable fields for the respective period. Seasonal extremes are represented by the periods of March-April and September-October. An empirical orthogonal function analysis of the monthly climatologies of the four predictor variables showed a

\footnotetext{
${ }^{6}$ www.cpc.ncep.noaa.gov/products/GODAS

ecmwf.int/en/research/climate-reanalysis/ocean-reanalysis

${ }^{8}$ apdrc.soest.hawaii.edu/datal
}

\section{Table 2}

Correlations between environmental predictor variables for monthly, $1^{\circ}$ binned TVOD presence/absence data $(n=126,460)$. Variables are surface temperature (TEMP), surface salinity (SAL), thermocline depth (TD), stratification index (SI) and distance to shelf edge (DIST).

\begin{tabular}{lcccc}
\hline & SAL & TD & SI & DIST \\
\hline TEMP & -0.54 & +0.03 & +0.73 & +0.10 \\
SAL & & +0.34 & -0.18 & +0.29 \\
TD & & & +0.58 & +0.56 \\
SI & & & & +0.46 \\
\hline
\end{tabular}

primary mode that explained $89 \%$ of the total variance and peaked in these months (not shown). These periods resolve important seasonal variations in the oceanography of the region (Fiedler and Talley, 2006). Two contrasting ENSO categories were based on mean NINO3.4 $\mathrm{SSTa}^{9}$ from July through June of the following year:

El Niño (NINO3.4 $>0.5^{\circ} \mathrm{C}$ ): 1986, 1987, 1991, 1994, 1997, 2002, 2004, 2009, 2014, 2015

La Niña (NINO3.4 $\left.<-0.5^{\circ} \mathrm{C}\right): 1988,1995,1998,1999$, $2000,2007,2010,2011$

Both these groups of years extend over the entire period of the 1986-2015 TVOD sightings data used to construct the model, which should help to reduce the influence of any temporal changes in data biases on the ENSO predictions. The effects of each of the predictor variables were assumed to be the same for each season or ENSO period, i.e. separate models were not built for each period, nor were interactions between season or ENSO periods (as factors) and the environmental variables included in the model. This means that the predicted model responses to season or ENSO period are directly determined by seasonal or ENSO-related changes in the predictor variables rather than by changes over time in the species-environment relationships.

The relative importance or contribution of predictor variables to a model prediction was estimated as in Thuiller et al. (2009). For a given model, each of the five variables were randomly permuted before being used in prediction. The correlation of the original prediction with the prediction using a permuted variable is related to the importance of the variable: permuting an unimportant variable will change the prediction only slightly and result in a high correlation, while permuting an important variable will result in more change in the prediction and a lower correlation. The scores of variable importance are equal to 1 minus the mean correlation for 20 random permutations of each variable, rescaled to sum to 1 across all predictor variables.

\section{RESULTS}

\section{Distributions in space: effects of season and El Niño/La Niña}

Spotted dolphin predicted probability of presence (Fig. 4) is highest in the eastern Pacific warm pool, although to the west of the warmest surface water off southern Mexico, Guatemala and Honduras (Fig. 1). Moderate levels of presence are predicted south of the equator, except in the cool Peru Current region off Peru and Ecuador. During

${ }^{9}$ www.cpc.ncep.noaa.gov/data/indices/sstoi.indices 
Spotted dolphin
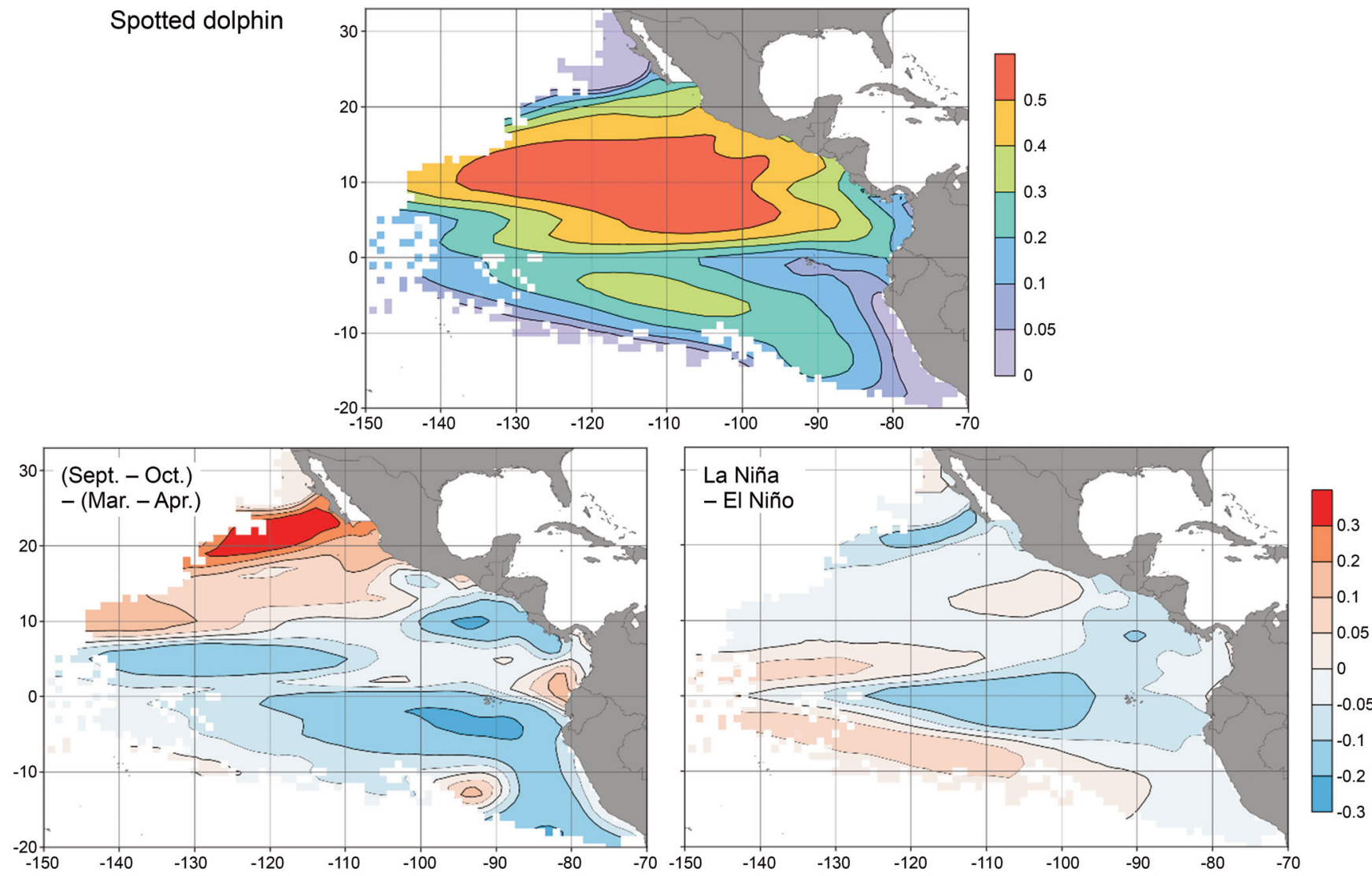

Fig. 4. Spotted dolphin probability of presence climatology (top), and differences between seasonal extremes and El Niño and La Niña years (bottom), predicted by GAM from TVOD, 1986-2015. Cells with $<300 \mathrm{~km}$ total TVOD effort are masked.

September-October and La Niña years, the normally low presence in the equatorial cold tongue declines (blue in the difference maps). From March-April to September-October, shifts are predicted from south to north across $\sim 10^{\circ} \mathrm{N}$, the thermal equator in the ETP (Fiedler and Talley, 2006) and away from Central American coastal waters, particularly the Costa Rica Dome. From El Niño to La Niña years, predicted presence shifts away from the equatorial cold tongue both to the north and south and also declines slightly in the region of the Costa Rica Dome and Gulf of Panama.

Spinner dolphin predicted probability of presence (Fig. 5) is restricted to the eastern Pacific warm pool between the equatorial front and the California Current off Baja California (Fig. 1). From March-April to SeptemberOctober, presence shifts toward the northwest extreme of the warm pool, similar to the prediction for spotted dolphins. From El Niño to La Niña years, changes are relatively minor. However, the increased probability of presence off southern Mexico during La Niña suggests that suitable habitat contracts to the warmest waters of the warm pool during cool years.

Common dolphin predicted probability of presence (Fig. 6) is high along the coast of southern Baja California, in the region of the Costa Rica Dome, and in the Peru Current and equatorial cold tongue. From March-April to September-October, predicted presence increases in the region of the Costa Rica Dome and in the equatorial cold tongue, but decreases in the Gulf of Panama region; the predicted presence maximum along Baja California moves to the north. Predicted presence along the countercurrent thermocline ridge $\left(\sim 10^{\circ} \mathrm{N}\right)$ increases slightly during September-October, when research vessel surveys had sightings here (see Fig. 8). From El Niño to La Niña years, predicted presence increases in the equatorial cold tongue and decreases in the Gulf of Panama, but there is no clear response to changes in the region of the Costa Rica Dome. The ENSO phase changes along southern Baja California are also not consistent with the seasonal changes.

Table 3 summarises the performance of the GAMs. AUC (area under the receiver operating characteristic curve) is an integral measure of the ability of the model to distinguish observed presences and absences, and COR (point biserial correlation) measures model goodness-of-fit to observations (Elith et al., 2006). The models explained a fair proportion of variance in the data and successfully predicted presence of dolphins. Correspondence between model-predicted presence and observed dolphin sightings in a research vessel database are examined below.

\section{Distributions in niche space}

Plots of available and utilised habitat (Fig. 7) illustrate the distributions of dolphins in ecological or niche space

Table 3

Performance of the GAM models in predicting the observed presence of three dolphin taxa: deviance explained, AUC and COR.

\begin{tabular}{lccc}
\hline & Deviance explained & AUC & COR \\
\hline Spotted & $21.4 \%$ & 0.85 & 0.64 \\
Spinner & $23.6 \%$ & 0.95 & 0.78 \\
Common & $23.2 \%$ & 0.82 & 0.43 \\
\hline
\end{tabular}




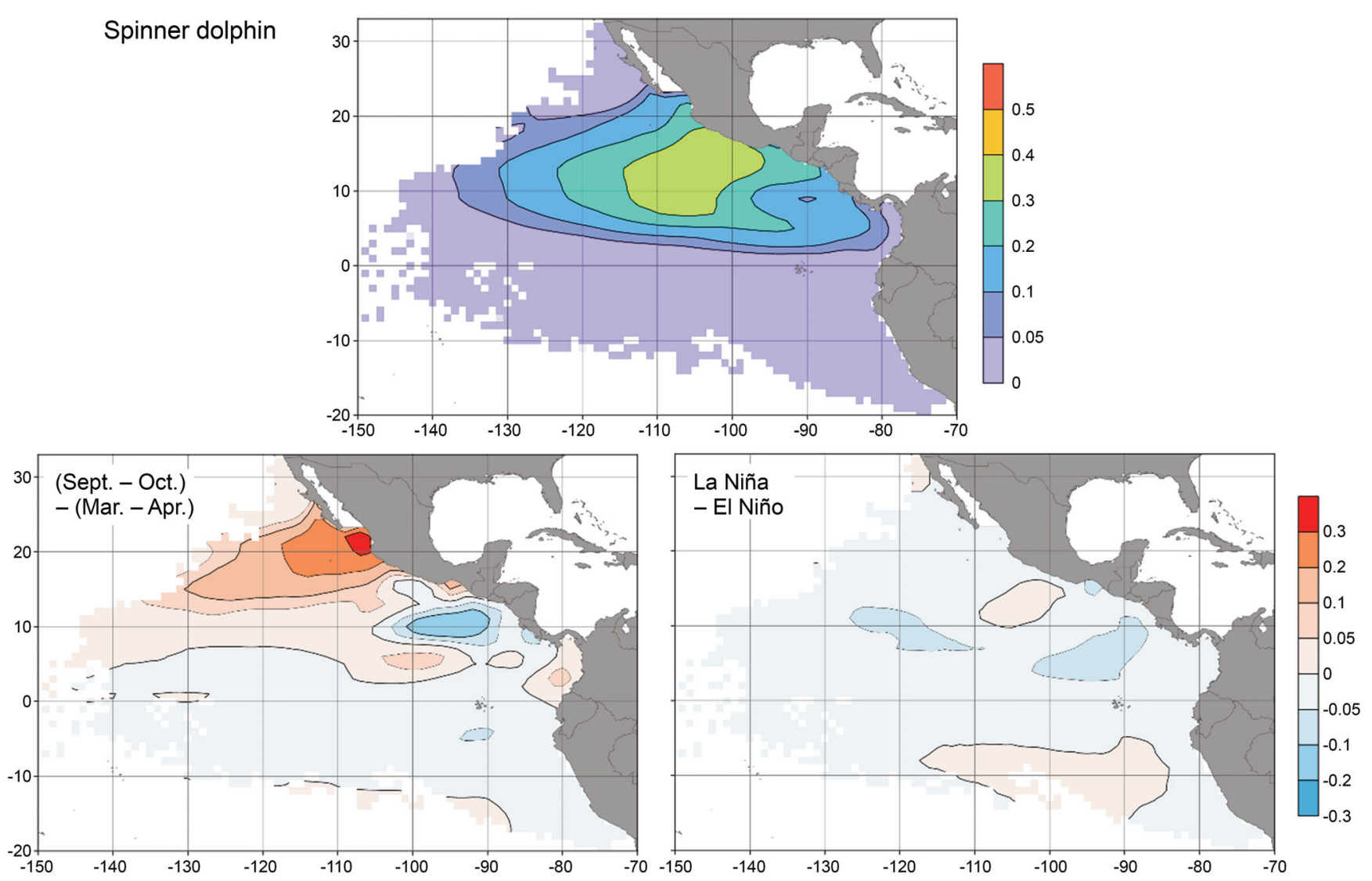

Fig. 5. Spinner dolphin probability of presence climatology (top), and differences between seasonal extremes and El Niño and La Niña years (bottom), predicted by GAM from TVOD, 1986-2015. Cells with <300km total TVOD effort are masked.

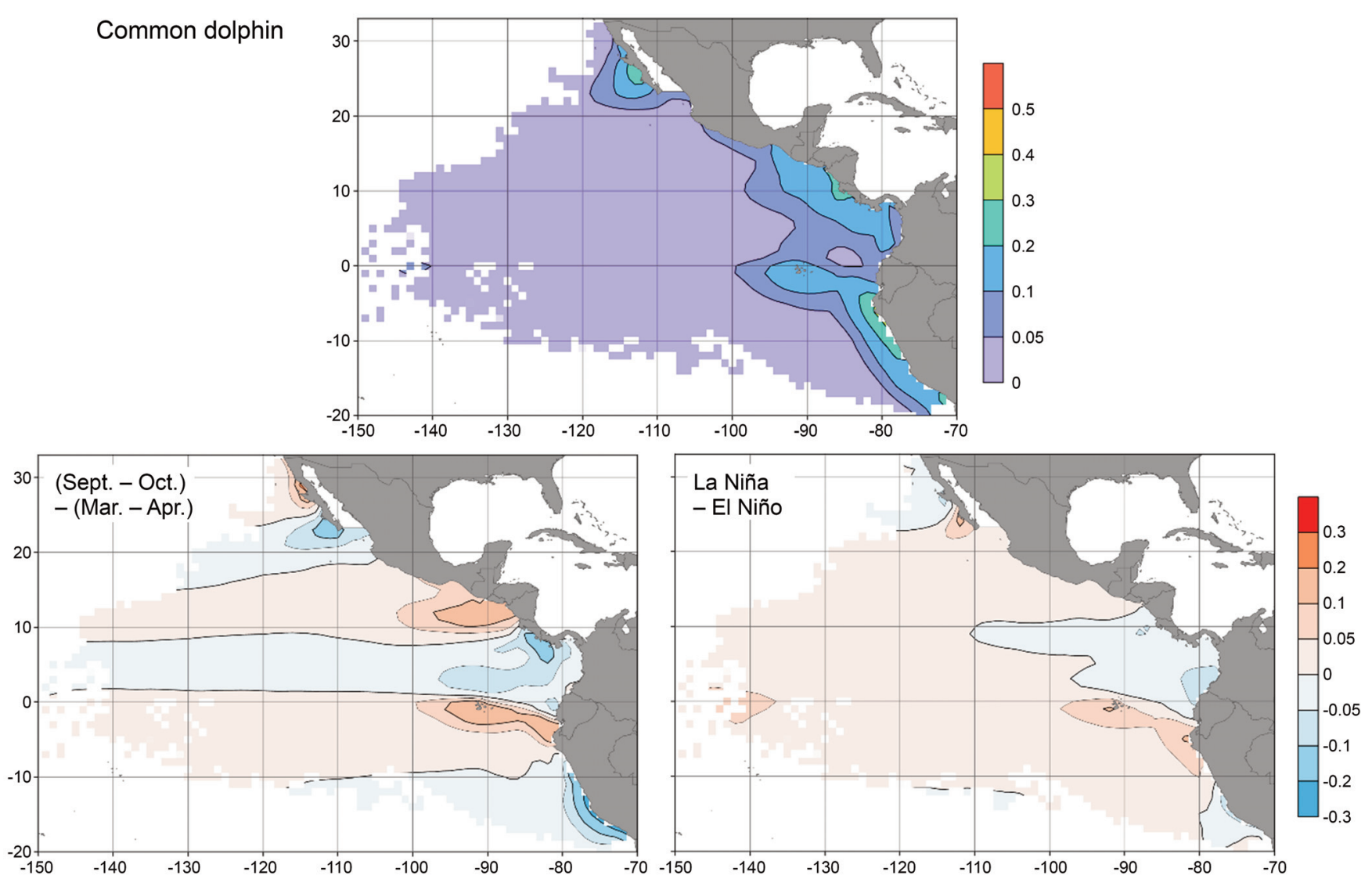

Fig. 6. Common dolphin probability of presence climatology (top), and differences between seasonal extremes and El Niño and La Niña years (bottom), predicted by GAM from TVOD, 1986-2015. Cells with <300km total TVOD effort are masked. 
sampled by the fishery as it searches for tuna associated with dolphins (for GAM partial response curves see the Appendix). These are essentially estimates of realised niches (Colwell and Rangel, 2009). The plot for the surface temperature-salinity interaction (TEMP-SAL) shows a predominance of the two major surface water masses in the region (Fiedler and Talley, 2006). The first is warm, moderate-salinity TSW centred at $28-29^{\circ} \mathrm{C}$ and $33-34 \mathrm{psu}$. The second is cooler, higher-salinity equatorial surface water (ESW) centred at $25-26^{\circ} \mathrm{C}$ and 34-35psu. Spinner dolphins are more strongly associated with TSW, while spotted dolphins show a broader distribution extending into ESW. Common dolphins too show a preference for ESW, but also for cooler waters representing coastal upwelling.

The other oceanographic variables, thermocline depth (TD) and stratification index (SI), are of similar relative importance as TEMP-SAL for all three dolphin taxa (Table 4). Spotted and spinner dolphins show a preference for a relatively strong but less shallow thermocline. Common dolphins show a distinctly different response to SI than spotted and spinner dolphins do; they prefer relatively unstratified near-surface waters, typical of coastal and oceanic upwelling regions. Distance to shelf edge (DIST) is
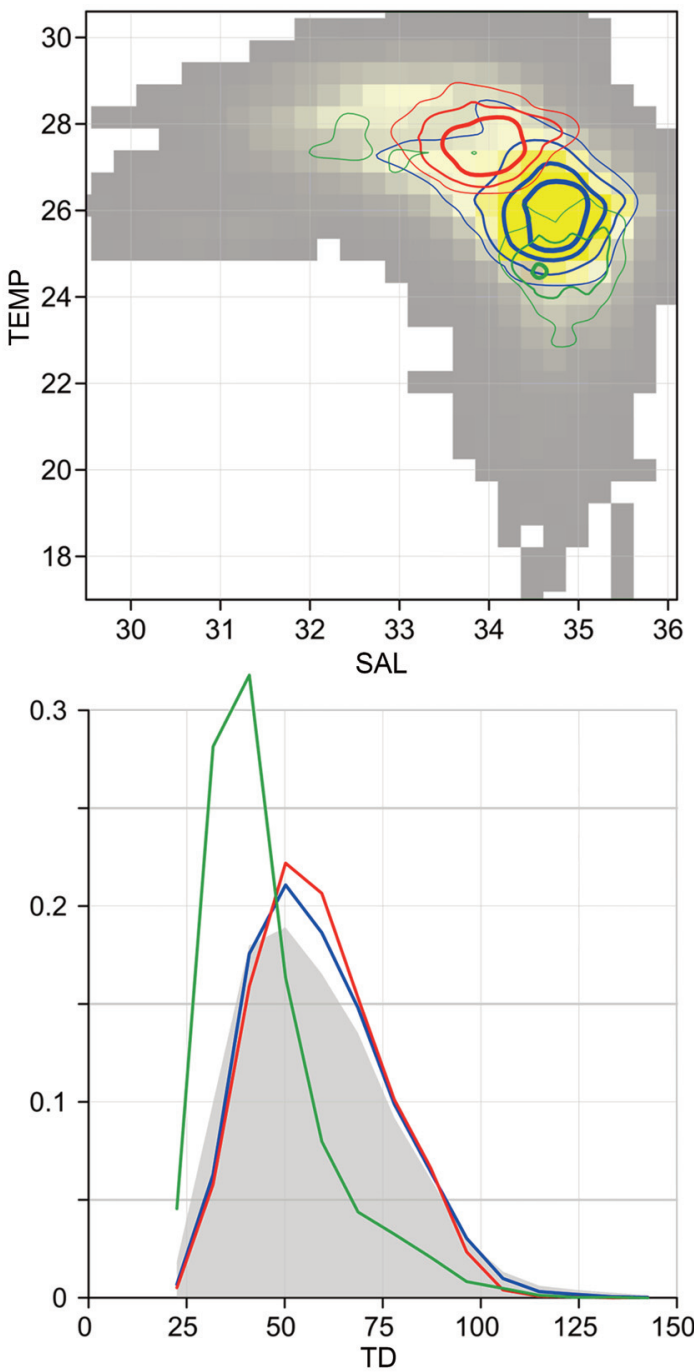

Table 4

Relative importance or contribution of predictor variables to GAM predictions of distributions of three dolphin taxa.

\begin{tabular}{lccccc}
\hline & TEMP-SAL & TD & SI & DIST & Effort \\
\hline Spotted & 0.36 & 0.27 & 0.26 & 0.03 & 0.08 \\
Spinner & 0.18 & 0.25 & 0.35 & 0.20 & 0.02 \\
Common & 0.19 & 0.20 & 0.23 & 0.34 & 0.04 \\
\hline
\end{tabular}

a relatively important predictor variable only for the more narrowly distributed spinner and common dolphins. For all of these predictor variables, the preferences of spotted and spinner dolphins, often found in mixed schools, are relatively similar, while they tend to be more distinct from the common dolphin preferences.

\section{DISCUSSION}

The GAMs of species-environment relationships using TVOD sightings were used to predict distributions for seasonal and ENSO periods from the climatological environmental conditions specific for those periods. These predictions could be made without extrapolating outside the limits of the TVOD observations, as would be necessary with
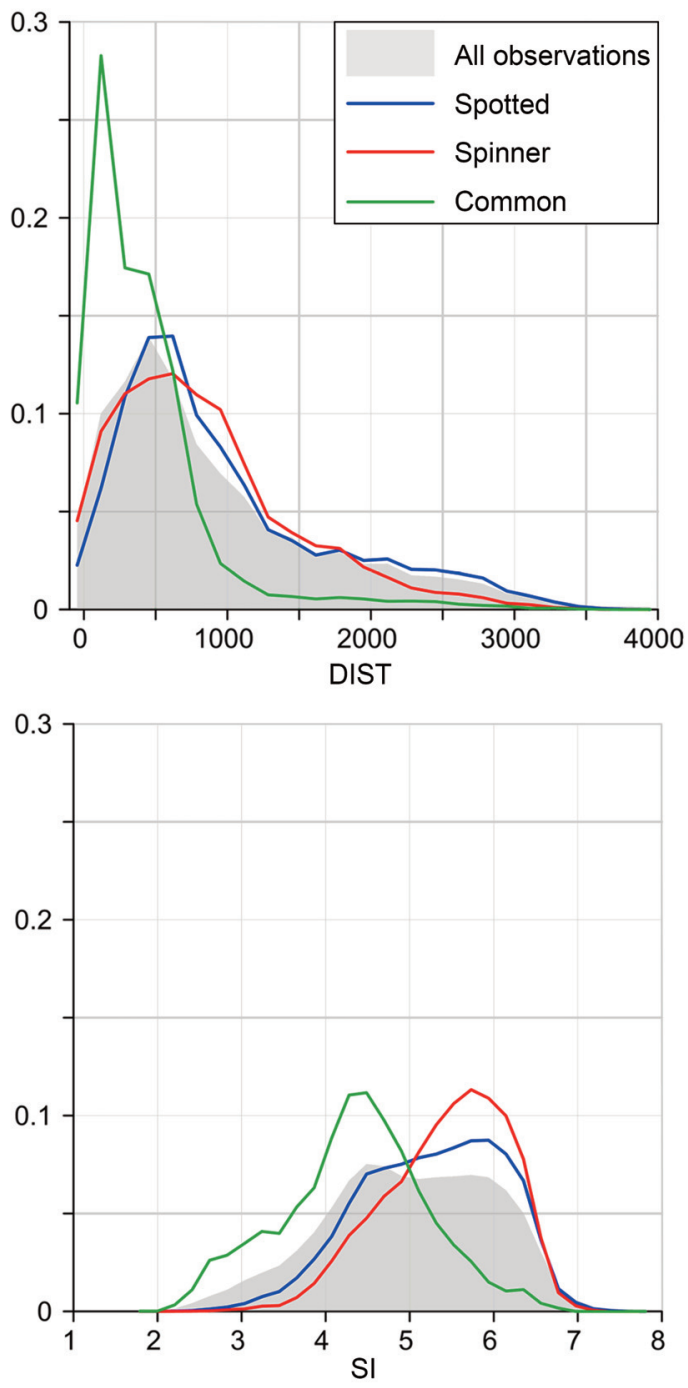

Fig. 7. Observed distributions of presence of three dolphin taxa (used habitat) and all month-deg observations (available habitat) relative to predictor variables: TEMP (surface temperature, ${ }^{\circ} \mathrm{C}$ ); SAL (surface salinity, psu); TD (thermocline depth, m); SI (stratification index, ${ }^{\circ} \mathrm{C}$ ); and DIST (distance to shelf edge, km). For the TEMP-SAL plot, contours are at 0.05, 0.1, 0.2 and 0.3 , colour-coded by taxon; availability ranges from 0 (darker grey) to 0.015 (yellow). 
models built from research vessel observations. The GAMs of species-environment relationships using TVOD sightings had explained deviance values of $21.4,23.6$ and $23.2 \%$ for spotted, spinner and common dolphins, respectively (Table 3). In comparison, GAMs of species encounter rates using SWFSC research vessel sightings and effort data had explained deviances of 11.6, 25.2 and $18.3 \%$ for offshore spotted, eastern spinner and short-beaked common dolphins (Forney et al., 2012). The results presented here give new insight into how these resident dolphins respond to seasonal and interannual changes within their habitat. Before discussing the ecological significance of the results, consideration is given to whether it is reasonable to make inferences about ETP dolphins based on observations of tuna-associated dolphins.

\section{Do TVOD results represent ETP dolphin populations?}

The overall correspondence between TVOD predicted distributions and the general distribution of Southwest Fisheries Science Center (SWFSC) research vessel sightings is good (Fig. 8), with correlations from 0.38 to 0.62 , although there are some discrepancies. For spotted dolphins, the
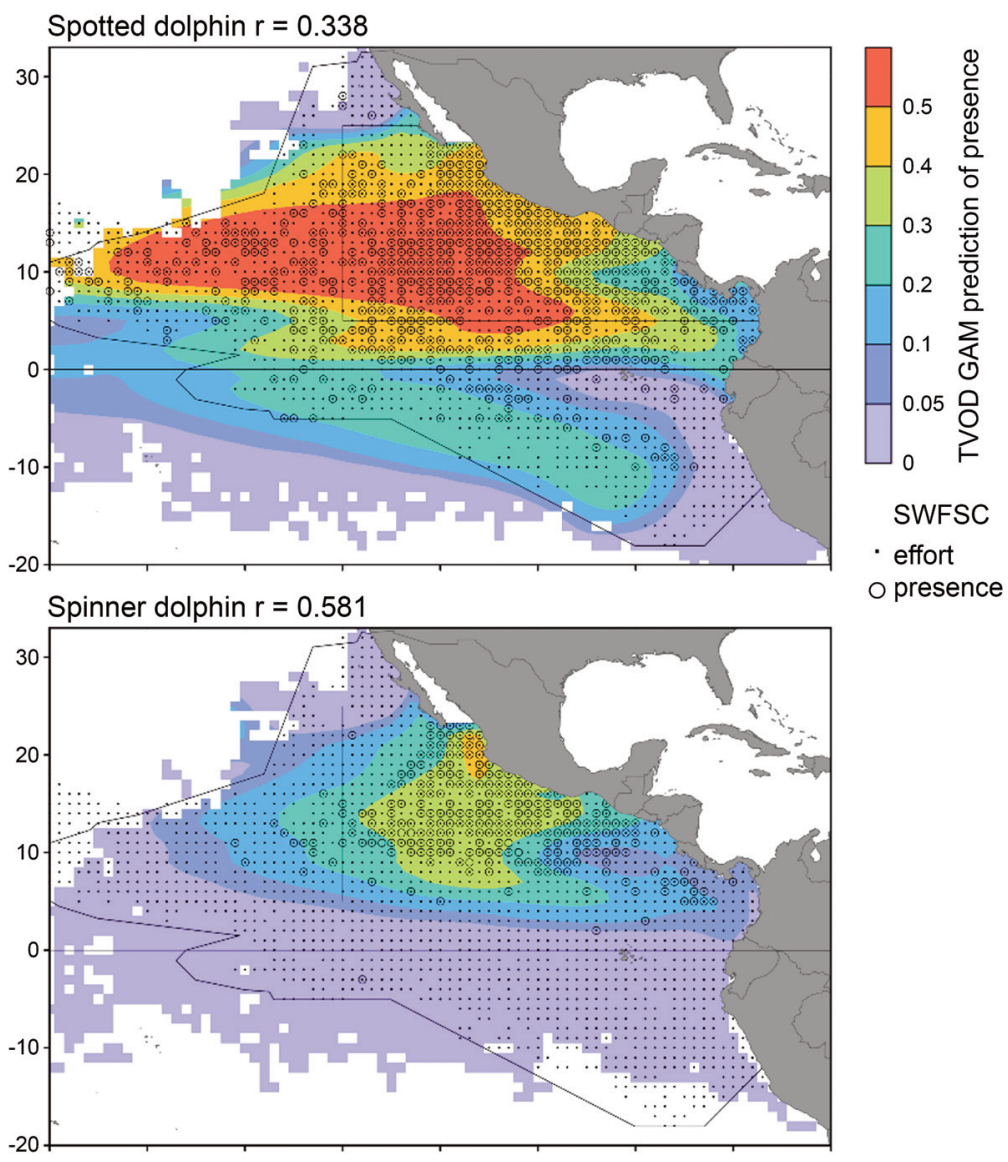

O presence

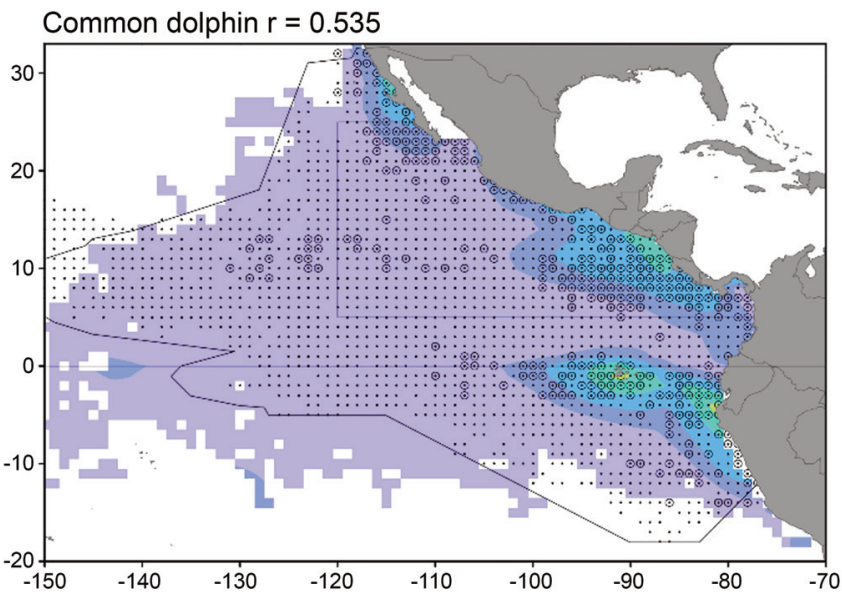

Fig. 8. Presence of three dolphin taxa predicted by GAMs from TVOD for AugustNovember (colour contours) and observed on 10 SWFSC research vessel surveys (symbols, no or at least one sighting 1986-2006) The outer line is the SWFSC study area and the inner line shows the core area for SWFSC surveys (Gerrodette et al., 2008). Predictions for cells with no TVOD effort are not shown. Correlations (r) between TVOD model prediction and SWFSC observed presence/absence in $1^{\circ}$ squares covered by both datasets. 
TVOD prediction tends to be higher to the west in the warm pool region, while SWFSC sightings are more prevalent to the east, likely because research vessel survey effort was nominally 2-3 times higher in the core area east of $120^{\circ} \mathrm{W}$. For spinner dolphins, research vessel sightings are most frequent in the warm pool area where TVOD predictions are highest. For common dolphins, research vessel sightings are frequent in three areas of coastal or equatorial upwelling as predicted: southern Baja California, the Costa Rica Dome and the coast of Peru-Ecuador extending west into the equatorial cold tongue. However, the TVOD predictions do not capture the research vessel sightings to the west of the Costa Rica Dome along the countercurrent thermocline ridge at $10^{\circ} \mathrm{N}$. Given the similarities, the spatial distributions and patterns of change presented here represent the responses of these dolphins to their environment in the ETP, whether or not they are associated with tuna.

Species distribution models for these species have been built from SWFSC research vessel survey data from the ETP, and also from the Central North Pacific and California Current. These models all estimate climatological distributions and may estimate distributions for individual survey years. For the ETP, Forney et al. (2012) show an eastern spinner dolphin distribution similar to that presented here (Fig. 5), with moderate expansion and contraction between surveys. Their predicted distributions for pantropical spotted dolphins show a preference for warm tropical water north of the equator, as in Fig. 4, but predicted levels are lower at the centre of the TVOD-predicted maximum (120 $\left.110^{\circ} \mathrm{W}\right)$ and higher to the west. Predicted density levels vary among surveys, but changes in distribution were not predicted. A related study that combined SWFSC data from the ETP and other regional surveys to model distributions in the central North Pacific found spatial patterns for pantropical spotted dolphins and spinner dolphins that are consistent with our results (Forney et al., 2015), even though spinner dolphins included whitebelly and Hawaiian spinners.

The distributions predicted for common dolphins by Forney et al. (2012) show the same three regional maxima in upwelling centres as in Fig. 6, but they emphasise the eastern equatorial maximum relative to the Costa Rica Dome and southern Baja California maxima. Pardo et al. (2015) used a single variable - absolute dynamic topography of the sea surface - to predict the distribution of short-beaked common dolphin population density using SWFSC survey data from the ETP and California Current. The pattern of preferred habitat was very similar to that presented here, but also had a moderate high corresponding to sightings to the west of the Costa Rica Dome.

\section{Ecological relevance}

The model-predicted presence of spotted dolphins is highest in a band along the countercurrent thermocline ridge at $10^{\circ} \mathrm{N}$, declining towards the coast of Central America, but extending towards the coast of southern Mexico (Fig. 4). Warm tropical surface water occupies this region, in a shallow layer overlying a strongly stratified thermocline (Fig. 1). Values of predicted presence tend to be greater to the west of $120^{\circ} \mathrm{W}$, although the prevalence of research vessel sightings of offshore spotted dolphins is greater to the east, in the core stratum of higher survey effort (Fig. 8).
Moderate levels of predicted presence of spotted dolphins extend to the south of the equator, but with a minimum along the equator corresponding to the equatorial cold tongue. Predicted presence is lower during September-October and during La Niña (Fig. 4), when the equatorial thermocline ridge is shallower and stronger trade winds increase equatorial upwelling and cool the surface waters. This exclusion is more pronounced for September-October than for La Niña. The primary seasonal change resolved by the difference map in the lower left of Fig. 4 is a summerautumn increase in the northern offshore part of the range and a decrease south of $\sim 10^{\circ} \mathrm{N}$. A decrease in predicted presence in the region of the Costa Rica Dome occurs during September-October, when the Dome is most fully developed (Fiedler, 2002). A similar, but smaller, change occurs during La Niña, when the Dome is slightly shallower than during El Niño (Fiedler and Talley, 2006).

The centre of predicted presence of spinner dolphins is confined to the warm, stratified eastern Pacific warm pool (Fig. 5), corresponding to the known distribution of the eastern spinner dolphin subspecies. The range limits of spinner dolphins correspond to the equatorial front to the south, and the presence of California Current and subtropical surface waters to the northwest. Seasonal changes in predicted presence of spinner dolphins are less than for spotted dolphins but are similar in showing a boreal summer-autumn increase towards the northwest. Changes in the region of the Costa Rica Dome are not marked. There are slight September-October and La Niña decreases at the Tehuantepec bowl off southern Mexico, which is also evident for spotted dolphins in Fig. 4. The Tehuantepec bowl, like the Dome, is associated with seasonal gap winds and the regional dynamics of surface circulation (Kessler, 2006).

Common dolphins have a distribution complementary to spotted and spinner dolphins in the ETP. Au and Perryman (1985) used early SWFSC abundance survey data to contrast the 'tropical water' habitat of spotted and spinner dolphins with the 'upwelling-modified' habitat of common dolphins. The model predictions indicate a strong response to the seasonal cycle of the Costa Rica Dome, with higher predicted presence of common dolphins in SeptemberOctober (Fig. 6). There is no strong response to the Dome predicted for La Niña years, but the increase in presence for the cold tongue region suggests a similar response to enhanced upwelling conditions during those periods. The concurrent decrease in predicted presence in the Gulf of Panama suggests that common dolphins might move to upwelling areas when habitat conditions are more favourable in those areas.

In both geographic and niche space, spotted dolphins and eastern spinner dolphins are partially sympatric, in that the range of the latter lies entirely within the range of the former, while common dolphins are more parapatric relative to the other two. All three dolphin species feed on a variety of small fishes, cephalopods and crustaceans, but diet differences may contribute to niche separation. Spotted dolphins in the ETP are known to feed on mesopelagic fishes and squids of the deep scattering layer, as it moves toward the ocean surface at night, and also on epipelagic fishes such as flyingfish (Robertson and Chivers, 1997). In contrast, spinner dolphins are known to dive deeper to feed more exclusively on 
mesopelagic prey (Perrin et al., 2008), potentially reducing niche overlap even though they are commonly found in mixed schools with spotted dolphins for at least part of the day (Scott and Chivers, 2009). Common dolphins feed on a variety of prey, including small mesopelagic fishes and squids found in the deep scattering layer and epipelagic schooling species such as small scombroids, clupeoids and market squids (Perrin, 2018a). The niche differentiation among these three species in the ETP is consistent with studies of other sympatric dolphins (Bearzi, 2005).

Useful information about the temporal and spatial distribution of dolphin prey species in the large oceanic region of the ETP does not exist. The predictor variables likely influence prey availability, notably thermocline depth and stratification (Scott et al., 2012). Spotted and spinner dolphins, which feed on vertically migrating mesopelagic prey, are associated with shallow thermoclines and high stratification, while common dolphins that feed on pelagic fish in upwelling areas show somewhat different associations with these proxy variables.

Our species distribution models for spotted, spinner and common dolphins based on TVOD have yielded new information about how the dolphins respond to seasonal and ENSO-related changes in their environment. These animals are highly mobile, opportunistic predators. The variations in habitat quality that determine model-predicted presence probably reflect prey availability influenced by the environmental proxies that were used as predictor variables. Tagging data for spotted dolphins have shown that they typically move $100-200 \mathrm{~km}$ per day, apparently in foraging activity (Scott and Chivers, 2009). Earlier tag-recapture studies found that some spotted dolphins moved several hundred $\mathrm{km}$ along the thermocline ridge at $10^{\circ} \mathrm{N}$ (Perrin et al., 1979). These observed movements are not true migration, as observed for some whales between distinct feeding and breeding/calving grounds (Stern and Friedlaender, 2018), but they are consistent with our results suggesting seasonal movements related to habitat seasonality. Both seasonal and interannual distributional responses to changes in habitat may indicate future effects of climate change in the region. Observing or predicting population responses will require more extensive collection and analysis of species density and life history data.

\section{ACKNOWLEDGEMENTS}

We thank the many fishery observers for collecting the sightings data, and Nicholas Vogel and Al Jackson for assembling the data. Robert Pitman provided helpful comments on an earlier version of the paper. Two anonymous reviewers also provided useful comments.

\section{REFERENCES}

An, S.-I. and Jin, F.-F. 2004. Nonlinearity and asymmetry of ENSO. J. Clim. 17:2399-412.

Au, D.W.K. and Perryman, W.L. 1985. Dolphin habitats in the eastern tropical Pacific. Fish. Bull. 83(4):623-43.

Ballance, L.T., Pitman, R.L. and Fiedler, P.C. 2006. Oceanographic influences on seabirds and cetaceans of the eastern tropical Pacific: A review. Prog. Oceanogr. 69(2-4):360-90.

Bayliff, W.H. 2001. Organization, functions and achievements of the InterAmerican Tropical Tuna Commission. Inter-American Tropical Tuna Commission Bulletin. Special Report 13. 122pp. [Available from: http://www.iattc.org].
Bearzi, M. 2005. Dolphin sympatric ecology. Mar. Biol. Res. 1(3):16575 .

Buckland, S.T. and Anganuzzi, A.A. 1988. Estimated trends in abundance of dolphins associated with tuna in the eastern tropical Pacific. Rep. Int. Whal. Commn 38:411-37.

Colwell, R.K. and Rangel, T.F. 2009. Hutchinson's duality: The once and future niche. Proc. Natl. Acad. Sci. U.S.A. 106(Suppl. 2):19651-58.

Committee on Taxonomy. 2017. List of marine mammal species and subspecies. Society for Marine Mammalogy, www.marinemammal science.org (acsessed on 15 April 2018).

Elith, J., Graham, C.H., Anderson, R.P., Dudík, M., Ferrier, S., Guisan, A., Hijmans, R.J., Huettmann, F., Leathwick, J.R., Lehmann, A., Li, J., Lohmann, L.G., Loiselle, B.A., Manion, G., Moritz, C., Nakamura, M., Nakazawa, Y., Overton, J.M.M., Townsend Peterson, A., Phillips, S.J., Richardson, K., Scachetti-Pereira, R., Schapire, R.E., Soberón, J., Williams, S., Wisz, M.S. and Zimmermann, N.E. 2006. Novel methods improve prediction of species' distributions from occurrence data. Ecography 29(2): 129-51.

Fiedler, P.C. 2002. The annual cycle and biological effects of the Costa Rica Dome. Deep Sea Res. I. 49:321-38.

Fiedler, P.C. 2010. Comparison of objective descriptions of the thermocline. Limnol. Oceanogr. Methods 8(6):313-25.

Fiedler, P.C. and Reilly, S.B. 1994. Interannual variability of dolphin habitats in the eastern tropical Pacific, II: Effects on abundances estimated from tuna vessel sightings, 1975-1990, Fish. Bull. 92:451-463.

Fiedler, P.C., Mendelssohn, R., Palacios, D.M. and Bograd, S.J. 2013. Pycnocline variations in the eastern tropical and North Pacific, 19582008. J. Clim. 26:583-99.

Fiedler, P.C. and Talley, L.D. 2006. Hydrography of the eastern tropical Pacific: a review. Prog. Oceanogr. 69:143-80.

Fiedler, P.C., Redfern, J.V. and Ballance, L.T. 2017. Oceanography and cetaceans of the Costa Rica Dome region. NOAA Tech. Mem. NMFS; NOAA-TM-NMFS-SWFSC-590. 34pp. [Available at: https://swfsc.noaa. gov/publications/TM/SWFSC/NOAA-TM-NMFS-SWFSC-590.pdf].

Forney, K.A., Becker, E.A., Foley, D.G., Barlow, J. and Oleson, E.M. 2015. Habitat-based models of cetacean density and distribution in the central North Pacific. Endang. Species Res. 27:1-20.

Forney, K.A., Ferguson, M.C., Becker, E.A., Fiedler, P.C., Redfern, J.V., Barlow, J., Vilchis, I.L. and Ballance, L.T. 2012. Habitat-based spatial models of cetacean density in the eastern Pacific Ocean. Endang. Species Res. 16:113-33.

Gerrodette, T. and Forcada, J. 2005. Non-recovery of two spotted and spinner dolphin populations in the eastern tropical Pacific Ocean. Mar. Ecol. Progr. Ser. 291:1-21.

Gerrodette, T., Watters, G., Perryman, W. and Ballance, L. 2008. Estimates of 2006 dolphin abundance in the eastern tropical Pacific, with revised estimates from 1986-2003. NOAA Tech. Mem. NMFS; NOAA-TMNMFS-SWFSC-422. pp 39 [Available at: https://swfsc.noaa.gov/ publications/TM/SWFSC/NOAA-TM-NMFS-SWFSC-422.pdf].

Hall, M.A. 1998. An ecological view of the tuna dolphin problem: impacts and trade-offs. Rev. Fish. Biol. Fisher. 8:1-34.

Hall, M.A., García, M., Lennert-Cody, C., Arenas, P. and Miller, F. 1999. The association of tunas with floating objects and dolphins in the eastern Pacific Ocean: A review of the current purse-seine fishery. pp.87-194. In: Special Report 11. Inter-American Tropical Tuna Commission, La Jolla, California. [Available at: http://www.iattc.org]

Hamilton, T.A., Redfern, J.V., Barlow, J., Ballance, L.T., Gerrodette, T., Holt, R.S., Forney, K.A. and Taylor, B.L. 2009. Atlas of cetacean sightings for the Southwest Fisheries Science Center Cetacean and Ecosystem Surveys: 1986-2005. NOAA Tech. Mem. NMFS 440.

Harris, P.T., Macmillan-Lawler, M., Rupp, J. and Baker, E.K. 2014. Geomorphology of the oceans. Mar. Geol. 352:4-24.

Hastenrath, S. 2002. The intertropical convergence zone of the eastern Pacific revisited. Int. J. Climatol. 22(3):347-56.

IATTC. 2018. Tunas, billfishes and other pelagic species in the eastern Pacific Ocean in 2017. Inter-American Tropical Tuna Commission, La Jolla, California.

Joseph, J. 1994. The tuna-dolphin controversy in the eastern Pacific ocean: biological, economic, and political impacts. Ocean Dev. Int. Law 25:130.

Kaschner, K., Quick, N.J., Jewell, R., Williams, R. and Harris, C.M. 2012. Global coverage of cetacean line-transect surveys: status quo, data gaps and future challenges. PLoS ONE 7(9):e44075.

Kessler, W.S. 2006. The circulation of the eastern tropical Pacific: a review. Progr. Oceanogr. 69:181-217.

Lennert-Cody, C.E., Buckland, S.T. and Marques, F.F.C. 2001. Trends in dolphin abundance estimated from fisheries data: a cautionary note. $J$. Cetacean Res. Manage. 3(3):305-19.

Lennert-Cody, C.E., Maunder, M.N., Fiedler, P.C., Minami, M., Gerrodette, T., Rusin, J., Minte-Vera, C.V., Scott, M. and Buckland, S.T. 2016. Purse- 
seine vessels as platforms for monitoring the population status of dolphin species in the eastern tropical Pacific Ocean. Fish. Res. 178:101-13.

Leslie, M.S. and Morin, P.A. 2018. Structure and phylogeography of two tropical predators, spinner (Stenella longirostris) and pantropical spotted (S. attenuata) dolphins, from SNP data. R. Soc. Open Sci. 5(4). [Available at: https://doi.org/10.1098/rsos. 171615].

National Research Council. 1992. Dolphins and the Tuna Industry. National Academy of Sciences, Washington. 176pp.

Pardo, M.A., Gerrodette, T., Beier, E., Gendron, D., Forney, K.A., Chivers, S.J., Barlow, J. and Palacios, D.M. 2015. Inferring cetacean population densities from the absolute dynamic topography of the ocean in a hierarchical Bayesian framework. PLOS ONE 10:e0120727.

Perrin, W.F. 2018a. Common dolphin. pp.205-9. In: B. Würsig, J.G.M. Thewissen and K. Kovacs (eds). Encyclopedia of Marine Mammals 3rd ed. Academic Press, London. 1,190pp.

Perrin, W.F. 2018b. Spinner dolphin. pp.925-8. In: B. Würsig, J.G.M Thewissen and K. Kovacs (eds). Encyclopedia of Marine Mammals 3rd ed. Academic Press, London, 1,190pp.

Perrin, W.F., Evans, W.E. and Holts, D.B. 1979. Movements of pelagic dolphins (Stenella spp.) in the eastern tropical Pacific as indicated by results of tagging, with summary of tagging operations, 1969-76. NOAA Tech. Rep. NMFS SSRF-737. 14pp.

Perrin, W.F., Robertson, K.M. and Walker, W.A. 2008. Diet of the Striped Dolphin, Stenella coeruleoalba, in the Eastern Tropical Pacific Ocean. Publications, Agencies and Staff of the U.S. Department of Commerce [Available at: http://digitalcommons.unl.edu/usdeptcommercepub/23].

R Development Core Team. 2017. R: A language and environment for statistical computing. R Foundation for Statistical Computing, Vienna, Austria. [Available at: $h t t p: / / w w w . R$-project.org/].

Redfern, J.V., Moore, T.J., Fiedler, P.C., De Vos, A., Brownell Jr, R.L., Forney, K.A., Becker, E.A. and Ballance, L.T. 2017. Predicting cetacean distributions in data-poor marine ecosystems. Divers. Distrib. 23:394 408. [Available at: http://www.wileyonlinelibrary.com].

Robertson, K.M. and Chivers, S.J. 1997. Prey occurrence in pantropical spotted dolphins, \{IStenella attenuata\}, from the eastern tropical Pacific. Fish. Bull. 95(2):334-48

Scott, M.D. and Chivers, S.J. 2009. Movements and diving behaviour of pelagic spotted dolphins. Mar. Mammal Sci. 25(1):137-60.

Scott, M.D., Chivers, S.J., Olson, R.J., Fiedler, P.C. and Holland, K. 2012. Pelagic predator associations: tuna and dolphins in the eastern tropical Pacific Ocean. Mar. Ecol. Prog. Ser. 458:283-302.

Stern, S.J. and Friedlaender, A.S. 2018. Migration and movement pp.60206. In: B. Würsig, J.G.M. Thewissen and K. Kovacs (eds). Encyclopedia of Marine Mammals. Academic Press, London. 1,190pp.

Thuiller, W., Lafourcade, B., Engler, R. and Araújo, M.B. 2009. BIOMOD - a platform for ensemble forecasting of species distributions. Ecography 32:369-73.

Wahlen, B.E. 1986. Incidental mortality of dolphins in the eastern tropical Pacific tuna fishery, 1973 through 1978. Fish. Bull. 84(3):559-69.

Wang, C. and Fiedler, P.C. 2006. ENSO variability and the eastern tropical Pacific: A review. Prog. Oceanogr. 69:239-66.

Ward, E.J. 2005. Differences between fishery-dependent and fisheryindependent estimates of single- and mixed-species dolphin schools: implication for single-species stock assessments. Mar. Mammal Sci. 21(2):189-203.

Wood, S.N. 2006. Generalized Additive Models: an introduction with R. Chapman and Hall, Boca Raton, Florida. 391pp.

Wood, S.N. 2008. Fast stable direct fitting and smoothness selection for generalised additive models. J. R. Statist. Soc. B70(3):495-518.

Wood, S.N. 2011. Fast stable restricted maximum likelihood and marginal likelihood estimation of semiparametric generalized linear models. $J$. $R$. Statist. Soc. B73(1):3-36.

\section{APPENDIX: MODELLED RESPONSES TO PREDICTOR VARIABLES}
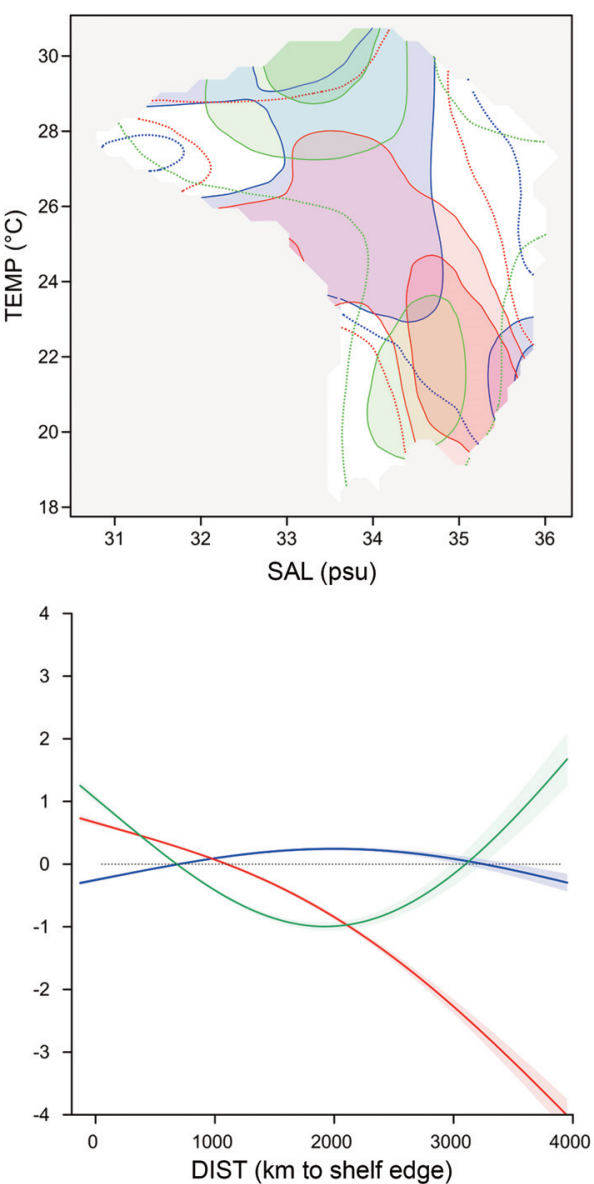
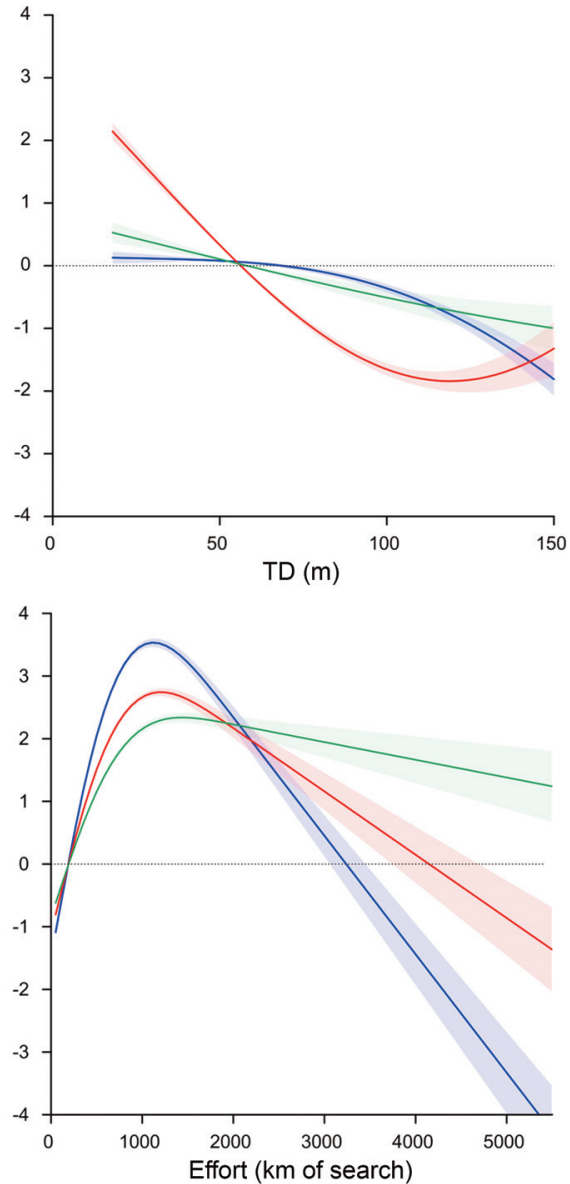
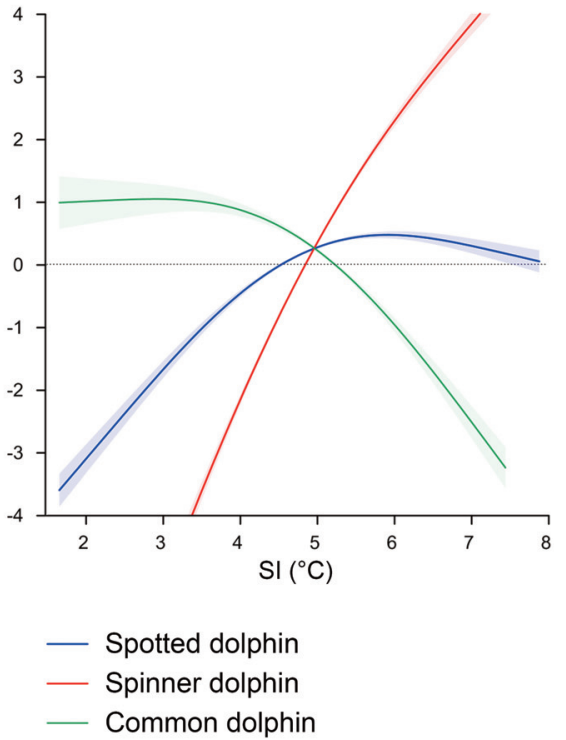

Appendix Fig. 1. Modelled responses to predictor variables for three dolphin taxa: TEMP (surface temperature); SAL (surface salinity); TD (thermocline depth); SI (stratification index); and DIST (distance to shelf edge). For the TEMP-SAL interaction plot, contours are at -1 (dashed), and at 0 and 1 (solid and filled); the grey area is outside the sample range. 